\title{
Wax finishing in Roman polychrome statuary: ganosis on the colossal head from Dougga (Tunisia)
}

Elisabetta Neri ${ }^{{ }^{*+}}$, Caroline Bouvier ${ }^{2+}$, Laurence de Viguerie ${ }^{2}$, Alain Brunelle ${ }^{2}$, Nesrine Nasr ${ }^{3}$, Fathi Béjaoui ${ }^{3}$, François Baratte ${ }^{4}$, Philippe Walter ${ }^{2}$

${ }^{1}$ Centre Européen d'Archéométrie, U.R. Art, Archéologie et Patrimoine, IPNAS, Sart Tilman B15, Université de Liège, 4000 Liège, Belgium.

${ }^{2}$ Sorbonne Université, CNRS, Laboratoire d'Archéologie Moléculaire et Structurale, LAMS, Paris, France

${ }^{3}$ Institut National du Patrimoine (INP), 04, place du château, Tunis 1008, Tunisia.

${ }^{4}$ Sorbonne Université, CNRS, Orient \& Méditerranée, UMR 8167, Paris, France.

+ These two authors contributed equally

* Corresponding author; e-mail: eneri@uliege.be 
Abstract

The material evidence for the wax finish on ancient marble statues, known as ganosis, is scarce and controversial, although Greek and Latin sources describe the recipes and cultural value of this treatment. The surface treatment of a colossal Roman head from the Roman theatre of Dougga (Tunisia), dated to the end of the second century CE, is studied by a multi-analytical protocol (video-microscope, cross section, and timeof-flight secondary ion mass spectrometry of one sample). The results of this physico-chemical analysis and the comparison with ancient recipes, prove the use of ganosis on a Roman statue and explore, for the first time, the application of the recipes described in ancient sources. This result shows the potential of the Time-of-Flight Secondary Ion Mass Spectrometry analysis, detecting at the same time organic and inorganic materials and their stratigraphy, to study the ancient recipes.
\end{abstract}

Keywords: beeswax, ganosis, statues, TOF-SIMS

\title{
1. Introduction
}

The polychromy of Roman statues is increasingly documented thanks to remarkable work carried out in the last 20 years, which has revealed the original appearance of painted statues thanks to the analysis of the pigments [1,2]. Conversely, the binders are less well documented; egg, proteinaceous and beeswax binders are rarely detected on the statues [3, 4] although many Greek and Latin written sources (Plutarch, Quaest. Rom., 287 b-d; Ovid, Fasti III, 831; Lucian, Imagines 23; Eusebius, Vita Costantini, I, 13) describe the use of wax, and a technique called ganosis. This wax finishing was specifically employed to fix a chromatic rendering, offering a weather-resistant protection for the statues which frequently stood out of doors. In particular, Pliny the Elder and Vitruvius offer further details about the type of wax employed and the recipes followed for the application of the wax on the wall and on the statues, and these have been long interpreted and debated [5, 6, 7]. Pliny distinguishes two older methods (Naturalis Historia, 35, 41) and one invented by Carthaginians for ships, the so-called "Punic wax". The first two methods consist in applying the hot wax in its molten state using a kind of broad-ended iron spatula-like tool (cauterium) or a punch (cestrum). The third method requires the application of the cold wax as a saponified emulsion. According to the recipe for the preparation of this emulsion (Naturalis historia, 21, 149), the wax is made soluble by boiling it in sea water with nitrum, a sodium carbonate. The process for its application on the statues is referred to in Vitruvius (De architectura, 7, 9, 3-4) and repeated by Pliny (Naturalis Historia 33, 122): punic wax and oil were mixed and applied with a brush, then charcoal was used to heat the surface and partially melt the coating to guarantee a better penetration and, finally, it is polished using candles and a white cloth. Greek sources attribute a ritual importance to the act of covering statues with wax [8]. Some sources, such as Plutarch (Moralia, 287b-c et d), consider it as a ritual procedure (therapeia) reserved to statues which are part of religious rites, and carried out before religious holidays. However, Vitruvius and Pliny, referring to the application of ganosis to wall painting, do not specify whether this practice was still ongoing as part of ritual care.

Despite this specific ancient literature and the detailed descriptions, material evidence relating to the use of Punic wax on statues has not been recognised with any certainty. The use of encaustic painting with Punic wax, widely documented in the series of portraits of the Fayum 
[9], is now evaluated with greater caution because of evident contamination with elements deriving from restoration procedures [10]. Only in the statue of the "beauty of Palmyra" (190$210 \mathrm{CE}$ ), silicates and beeswax probably without fatty acids have been detected by FT-IR. The absence of fatty acids is interpreted as the use of Punic wax, without being able to specify whether this is a binder or a surface finish [11]. Conversely, two Hellenistic statues testify to a hot beeswax application. The presence of a thick layer of wax without mineral addition is detected, by SEM-EDS, chromatography and FT-IR, on a head of Berenice II ( $3^{\text {rd }} \mathrm{C}$. BC) at the Mariemont museum [12,13]. The same treatment is presumed for the "Sinnende Muse" of Dresden, but analytical results are still unpublished and just a mention is known [14]. In other Greek statues the detection of modern synthetic resin and oil mixed with wax suggests a modern conservative intervention $[15,16]$. Beeswax may be applied as a protective agent during a modern conservation treatment to confer water repellency to to prevent degradation by salts.

\subsection{Research aims}

In this study we present the analysis of a colossal marble head from the theatre in Dougga, not restored after the discovery, in which the a multi-layered application of different types of beeswax is demonstrated for the first time. The complexity of multi-material (organic and inorganic) and multi-layered samples, as well shown for the gilding by Bonaduce and Boon [17], request a multi-analytical approach and an imaging technique such as the Time-of-Flight Secondary Ion Mass Spectrometry (TOF-SIMS), detecting at the same time organic and inorganic materials and their stratigraphy. In this paper we apply for the fist time this technique to a polychromy remains of a roman statues and we compare our results with the roman recipes of ganosis described by Pliny and Vitruvius.

\section{2. $\quad$ Material and methods}

In the frame of the project «Corpus of the statues of the Bardo museum», directed by Francois Baratte and Fathi Bejaoui, an unpublished marble head from Dougga has been studied (Inv. 010326 14). This statue was discovered during the 1927 excavation by the «Direction des Antiquités », against the west wall of the theatre, at the main gate (fig. 1 and 2 ). The position of the discovery and the dimension of the head $(44.5 \times 26 \times 31 \mathrm{~cm})$ indicate that it belonged to a colossal statue decorating the theatre, standing outside. After its entrance to the Bardo museum (on 13th May 1927), this head was not restored and has been stored in a museum warehouse in Carthage.

The formal study [18] suggested that this head was reworked from a Julio-Claudian statue because of the treatment of the hair- during the final part of the $2^{\text {nd }}$ or at the beginning of the $3^{\text {rd }}$ century CE. The features do not allow for its identification as an official portrait of the Emperor, and the identity of the character remains unknown. The formal treatment and the style of the head, make it close to the portrait of Probus in the Capitoline Museums [19, p. 139-141, n 116, pl. 143-144]. 
This head was examined in situ with a video-microscope (Dino-lite 500-550x) in white light and UV light. A micro-sample was taken from the lips, embedded in an epoxy resin polished and observed with a Nikon Eclipse LV100ND microscope under different light conditions.

This sample was analysed by TOF-SIMS to investigate the nature of the pigments and binders in the different layers. Each layer can be examined independently thanks to the imaging abilities of the TOF-SIMS technique, giving simultaneous localisation and identification of both inorganic and organic materials from the analysed surface on a sub-micrometre scale. The mass spectrum allows identification, and in addition the imaging spatially separates the information, which gives the localisation of the identified compounds. Combining the two, we can then access the individual composition of each layer in a stratigraphy. The recorded ion images reveal spatial information with a $390 \mathrm{~nm}$ pixel size $[20,21]$ and the mass spectra are generated with a mass resolution (that is $\mathrm{M} / \Delta \mathrm{M}$, FWHM) of a few thousands thanks to the delayed extraction of secondary ions with which the instrument is equipped [22]. Micrometre size pigment grains can be identified [23], and layers thinner than $10 \mu \mathrm{m}$ are adequately resolved so their composition can be discriminated in the spectral data using regions of interest (ROIs).

The TOF-SIMS analyses were performed on a TOF-SIMS IV (IONTOF GmbH, Germany) in the Laboratory of Molecular and Structural Archaeology (LAMS, CNRS - Sorbonne University, Paris, France). The raw data were acquired using SurfaceLab 6.7 software (IONTOF GmbH, Germany) and processed with SurfaceLab 7.0. The instrument is equipped with two ion sources. A Liquid Metal Ion Gun (LMIG) serves as the primary ion source for analysis purposes, while an argon Gas Cluster Ion Beam (GCIB) allows one to gently sputter the surface without damaging the underlying layers.

The GCIB was used to clean the sample surface in the instrument chamber prior to analysis. The source was tuned to emit a beam of 2000 Ar atoms clusters with a total kinetic energy of $10 \mathrm{keV}$, and the sputtered area was a square more than twice the size of the analysed area, to avoid border effects of the cleaning step. The contaminants on the surface were sputtered, as shown by the decrease of the signal associated to the $\mathrm{SiC}_{3} \mathrm{H}_{9}{ }^{+}$ion $(\mathrm{m} / z$ 73.05) coming from the recurring surface plastic additive polydimethylsiloxane (PDMS). After that step, the cleaned surface was analysed using the LMIG tuned to emit a bismuth cluster pulsed ion beam of $25 \mathrm{keV}$ kinetic energy $\left(\mathrm{Bi}_{3}{ }^{+}\right)$, impacting the surface at an angle of $45^{\circ}$. A low energy electron flood gun neutralizes the residual charges on the surface between the various steps of the analysis.

The analyses were carried out with the so-called "burst alignment with delayed extraction" $(\mathrm{BA}+\mathrm{DE})$ focusing mode of the LMIG beam, giving the best spatial resolution on this instrument. The focusing mode termed "high current bunched" (HCBU) was used in parallel to calibrate the mass spectra, thanks to the linearity between the time-of-flight and the $\mathrm{m} / \mathrm{z}$, which is lost when using $\mathrm{BA}+\mathrm{DE}$. In this latter case, the mass calibration is refined by using known heavy ions peaks from the marble, like $\mathrm{Ca}_{\mathrm{m}} \mathrm{O}_{\mathrm{n}}{ }^{+}$in positive ion mode and $\mathrm{Ca}_{\mathrm{n}} \mathrm{O}_{\mathrm{m}}{ }^{-}$in negative ion mode $(m>n)$.

Two areas (see Fig. 3) were imaged with TOF-SIMS, spanning all the stratigraphy: marble, pigmented red layer, first finishing layer, second finishing layer. To help identify which secondary ions are to be sought in the sample spectra in order to then identify the ingredients, reference compounds were analysed in the same analytical conditions: modern beeswax, 
commercial Punic wax (Rami, Lavaris) and sodium carbonate (dehydrated natron, which was used in its natural hydrated form in Pliny's recipe (Naturalis historia, 21, 49). Beeswax is an organic compound in which the major component is myricyl palmitate, a fatty acid ester. In the following, the presence of this molecule will be used as a wax marker.

BA+DE analyses of the statue sample were carried out on $100 \mu \mathrm{m} \times 100 \mu \mathrm{m}$ square surfaces divided into $256 \times 256$ pixels or $50 \mu \mathrm{m} \times 50 \mu \mathrm{m}$ square surfaces divided into $128 \times 128$ pixels. The primary ion dose was $1.10^{12}$ ions per $\mathrm{cm}^{2}$, below the so-called "static SIMS limit", which ensures that the analysed surface is free of any damage during and after the measurement. HCBU analyses of the reference compounds were carried out with a primary ion dose of about $1.10^{12}$ ions per $\mathrm{cm}^{2}$, on $150 \mu \mathrm{m} \times 150 \mu \mathrm{m}$ square surfaces divided into 256 $\times 256$ pixels.

\section{Results and discussion}

The visual examination shows the remains of colours in lips (red), hair (black), nose (yellow). These traces of colour could also be observed with the video-microscope: black in the eyes and the eyebrows, red partially superimposed on yellow on the lips, brown and black in the hair with some blue points between the nape and the hair (fig. 2). The skin displayed a yellow treatment. A slight fluorescence was observed under UV illumination in the skin, lips, hair and in the forehead. Some parts of the statue were particularly accentuated, such as the eyes, lips and hair.

The micro-sample taken between the lips shows a red layer above the marble layer, and two white layers on top of this one, slightly fluorescent (fig. 3).

The TOF-SIMS data give access to the chemical composition and the stratigraphy of the different layers in the two areas analysed, which were chosen so as to include all the layers, from the marble to the uppermost surface. Their composition, identified by the detection of characteristic ions,attested also in the modern standard references with wellknown compositions, are described in Table 1.

The hematite is identified through iron peaks, the pure beeswax is identified through the detection of characteristic fragment ion peaks of myricyl palmitate, which is its major component, as well as in Bonaduce and Boon [17]. Another type of beeswax, showing the same peaks, co-localized with the characteristic peaks of natron, could be the Punic wax. The same peaks have observed in the reference of modern "Punic wax" and according the Pliny recipes (Naturalis historia, 21, 149), the "Punic wax" is made boiling the common beeswax in sea water with nitrum. In this paper, we call "Punic wax" this peculiar beeswax mixed with salts, following the Pliny definition of "Punic wax".

The analysis indicates that the marble is covered by a layer made of grains of haematite with "Punic wax" as the binder (fig. 4). In the superficial white layers calcium and lead are not detected, which rules out the presence of white paint in these two layers. The red pigment layer is covered with a layer of "Punic wax" which is in turn covered with a layer of pure beeswax. 
Comparing the reference mass spectra with those extracted from the different layers of the samples, as shown in Fig.4, the spectra from both analysed areas (showing positive ions for area $\mathrm{A}$ and negative ions for area $\mathrm{B}$ ), are comparable to the reference spectra of pure beeswax, haematite-rich ochre (Kremer Pigmente) and dolomite marble (Kremer Pigmente), in the positive ion mode; and pure beeswax, saponified wax and sodium carbonate (dehydrated natron), in the negative ion mode.

Other ions like those at $\mathrm{m} / \mathrm{z} 473,509,557$ and 767 are detected in the sample but not in the reference. As described by Stacey et al. [5], compounds like sodium carboxylate are formed in the preparation processes both in cases of Punic wax and alkali-treated wax, but the composition of the media is dependent on the treatments made. It is therefore difficult to link the detection of a compound to a specific processing technique. In this work, we show that the two layers containing wax are however distinguishable through the detection of sodium carbonate characteristic ions, only present in the deeper layer, suggesting a difference in preparation. As free fatty acids are also detected, it can suggest that the wax was not fully saponified, explaining why we are able to detect natron characteristic ions as well.

However, these ions mentioned in the previous paragraph can be attributed to the adducts of the beeswax characteristic ion $\mathrm{C}_{24} \mathrm{H}_{57} \mathrm{O}_{2}^{-}$with several sodium-containing ions. Such compounds could be explained by a long-term degradation process due to the reaction between wax molecules and natron, consistent with their absence in the reference. Regert et al. [24], whose study aimed at understanding the composition of ancient beeswax residues, make no mention of the apparition of such sodium-containing compounds, so another explanation could be that the wax used had a slightly different composition than the references, or that the natron contained some impurities.

The comparison between the negative ion mass spectra extracted from the two superficial layers and the reference mass spectra of beeswax, saponified wax and pure natron (fig. 5a) allows one to discriminate the localisation of the Punic wax in the stratigraphy, thanks to the characteristic ions detected in the Punic wax and not in beeswax. These ions are detected in the paint layer and the one above it, while only the beeswax markers are detected in the uppermost layer.

The spatial distribution of the components corresponds to the stratigraphy observed in the cross section (marble, painting and two white layers) (fig. 3; fig. 5e), showing the localisation of Punic wax and beeswax respectively in the lower and upper white layer. The analysis suggests the use of Punic wax as the binder, since it is mixed with haematite in the paint layer, and as a protecting agent, notably in the surface. The presence and the distribution of Punic wax in these two layers are corroborated by the distribution of the markers of the sodium carbonate reference. The distribution of sodium-containing ions has in fact the same shape as these red and white layers superimposed on the marble. The use of hematite in the lower layer is consistent with the shadowing using brown-red pigments, as formerly observed by Delaney et. al on ancient techniques [26].

The analysis of this sample not only confirms the use of wax as a binder and a protecting agent, but also shows that the recipes described by Vitruvius and Pliny (De architectura, 7, 9, 3-4; Naturalis Historia 33, 122) are applied to this second-third-century African statue. According to the recipes, the Punic wax is applied at first with a brush on the pigment, and 
secondly a polishing with beeswax candles is performed. A change in the application technique can be deduced from the comparison between this treatment and the two other Hellenistic statues in which the presence of wax is attested $[11,12,13]$. If the wax is applied hot in the two Hellenistic statues, in the Dougga head it is the cold technique that is employed with the Punic wax. This proves that the recipe transmitted by the Roman Imperial written sources is not only a literary tradition, but that the recipe is actually followed in practice at least until the end of second century CE.

In the colossal head of Dougga the act of covering the painted surface of first covering the painted surface with Punic wax, and then again with Punic wax before a final polish with beeswax, is a remarkable effort, because paintings with wax were highly prized [25, p. 67]. Moreover, the finishing with wax has undoubtedly a practical function, as a fixing and protecting agent for the colour.

\section{Conclusion}

The chemical results highlight the importance of this statue, which stood outdoors, probably depicting an important private citizen. The dimensions of this statue and the finish evidence underline its high value. The analytical protocol adopted allows one to document with precision the waxing recipes followed, and to identify for the first time the new treatment of ganosis and to compare the stratigraphy of the samples with the gestures and the material described byVitruvius and Pliny. Moreover, the analysis suggests a possible link between the archaeological materials and the recipes of Pliny and Vitruvius: a wax finishing with Punic wax and a polishing with wax from candles.

In the future, an increased number of identifications on statues of different chronologies and provenance will make it possible to understand further in which chronological period and which geographical area these ancient recipes have been used and how the Greek use of ganosis [26, 27] evolves in the Roman period. By extending the analysis to statues of a different nature (cultural and decorative), it will be possible to understand if, as the sources state, the waxing had a socio-religious meaning.

\section{Acknowledgements}

Faouzi Mahfoudh, director of INP at Tunis, and Fatma Nait Yghil, director of Bardo museum, are warmly acknowledged having authorized the in situ analyses and the micro-sampling. The authors are also grateful to Helen Glanville for sample preparation and for reading and improving the manuscript, and Johanna Salvant who took the photographs of the sample under the microscope.

The fieldwork for this study was supported by the Coblarcheo program (Paris-Sorbonne: program Convergence 2016 at LAMS laboratory) and in the frame of the project "Corpus des sculptures du Musée du Bardo-Tunis", headed by Francois Baratte and Fathi Bejaoui. This work was financially supported by the Agence Nationale de la Recherche (France, grant ANR-2015-CE29-0007 DEFIMAGE). This project has received funding from the European Union's Horizon 2020 research and innovation programme (grant agreement "PolyCRomA: No. 89600 to EN). The funding organisation had no influence in the study design, data collection and analysis, decision to publish, or preparation of the manuscript. 
1

Captions

Fig. 1: The context of the discovery of the statue analysed: the theatre of Dougga. (a) Plan drawn after the excavations; (b) view in 1931; the main entrance in the west wall, where the statue was discovered, is highlighted (Archives de la Planète - Collection Albert Kahn - photo F. Gadmer).

Fig. 2: (a) Head of male statue from Dougga (Inv. 010326 14) in its actual state of conservation; (b) macro-photography of the lips with traces of red and yellow painting and (c) black on the hair; micro-photography (Dino-lite $\times 200$ ) of the same areas showing the stratigraphy: (d) on the lips yellow, red and white layer superposed; (e) on the hair yellow and black superposed.

Fig. 3 Cross-section of the sample (lips), (a) observed in visible light in cross-polarisation, showing the stratigraphy (from the bottom to the top): marble, red layer with pigment particles, white opaque layer and white translucent layer observed only on the right; (b) UV fluorescence confirms the stratigraphy: pigment layers appear black, and the two white layers have a fluorescence different to that of the marble. Yellow squares highlight the analysed areas $(\mathrm{A})$ and $(\mathrm{B})$.

Fig. 4: Mass spectra from the analysed areas of the statue sample, and reference compounds: (a) positive ions, statue sample, zone (A) (see Fig. 3a), with inserts showing haematite, marble, beeswax and ions characteristic of Punic wax; (b) positive ions, dolomite reference (Kremer Pigmente $n^{\circ} 58740$ ) (blue) and red ochre reference (Kremer Pigmente $n^{\circ} 40510$ ) (red); (c) positive ions, pure beeswax reference. (d) negative ions, statue sample, zone (B) (see Fig. 3a), with beeswax and Punic wax characteristic ions; (e) negative ions, natron reference (dark red) and saponified wax (blue); (f) negative ions, pure beeswax reference.

Fig. 5: (a) Negative ion mass spectrum of layer 4; (b) Negative ion mass spectrum of layer 3; (c) negative ion mass spectrum of saponified wax reference, in red the negative ion mass spectrum of pure natron reference; (d) negative ion mass spectrum of pure beeswax reference; (e) Microscope image of the cross-section with the locations of the two analysed areas A and B. The four small images are from left to right, the optical, total ion images and images of characteristic ions from Table 1 for wax (red), and for natron (blue). The images on the right are their overlays. Images have a $50 \mu \mathrm{m}$ side for zone A and a $100 \mu \mathrm{m}$ side for zone B. The layers are delineated with dotted white lines to guide the eye.

Table 1 : Characteristic ions from reference mass spectra and detected in the sample.

References

[1] M.B. Abbe, Polychromy, in: E.A. Friedland, M.G. Sobocinski, E.K. Gazda (Eds.), The Oxford Handbook of Roman Sculpture, Oxford University Press, Oxford, 2015, pp. 173-188. 
[2] J.S. Østergaard, Polychromy of Greek and Roman sculptural,, in: The Oxford Classical Dictionary, Oxford University Press, Oxford, 2018.

[3] H. Brecoulaki, A. Andreotti, I. Bonaduce, M.P. Colombini, A. Lluveras, Characterization of organic media in the wall-paintings of the "Palace of Nestor" at Pylos, Greece: evidence for a secco painting techniques in the Bronze Age, Journal of Archaeological Science 39 (2012) 2866-2876.

[4] C. Brøns, K.L. Rasmussen, M. Melchiorre Di Crescenzo, R. Stacey, A. Lluveras-Tenorio, Painting the Palace of Apries I: ancient binding media and coatings of the reliefs from the Palace of Apries, Lower Egypt, Heritage Science 6 (2018), 2866-2876.

[5] R.J. Stacey, J. Dyer, C. Mussell, A. Lluveras-Tenorio, M.P. Colombini, C. Duce, J. La Nasa, E. Cantisani, S. Prati, G. Sciutto, R. Mazzeo, S. Sotiropoulou, F. Rosi, C. Miliani, L. Cartechini, J. Mazurek, M. Schilling, Ancient encaustic: An experimental exploration of technology, ageing behaviour and approaches to analytical investigation, Microchemical Journal 138 (2018), 472-487.

[6] A. Freccero, Wax paint and Punic wax - research and experiment, in: S. Omarini (Ed.), Encausto: Storia, Tecniche e Ricerche = Encaustic: History, Technique and Research, Nardini, Firenze, 2012, pp. 105-113.

[7] S. Omarini (Ed.), Encausto: Storia, Tecniche e Ricerche = Encaustic: History, Technique and Research, Nardini, Firenze, 2012.

[8] E. Leka, La thérapéia des scultpures en Grèce ancienne : le témoignage des sources textuelles, in: B. Bourgeois (Ed.), Thérapéia. Polychromie et restauration de la sculpture dans l'Antiquité (Techné, 40), Paris, pp. 61-68.

[9] B. Ramer, The Technology, Examination and Conservation of the Fayum Portraits in the Petrie Museum, Studies in Conservation 24 (1) (1979), 1-13.

[10] C.G. Lalli, G. Lanterna, D. Andrash, F. Innocenti, The rewiew of analytical data of te Fayum in the light of new investigations technique", in: S. Omarini (Ed.), Encausto: Storia, Tecniche e Ricerche = Encaustic: History, Technique and Research, Nardini, Firenze, 2012, pp. 114-122.

[11] M.L. Sargent, R.H. Therkildsen, The Technical Investigation of Sculptural Polychromy at the Ny Carlsberg Glyptotek 2009-2010 - An Outline, in: Tracking colour. The Polychromy and Greek and Roman Sculpture in the Ny Carlsberg Glyptotek. Report 2, Copenhagen, 2010, pp. 11-27.

[12] B. Bourgeois, (Re)peindre, dorer, cirer. La thérapéia en acte dans la sculpture grecque hellenistique, in: B. Bourgeois (Ed.), Thérapéia. Polychromie et restauration de la sculpture dans l'Antiquité (Techné, 40), Paris, 2014, pp. 69-80.

[13] N. Balcar, J. Langlois, Y. Vandenberghe, Caracterisation d'une cire d'abeille sur un portrait en marbre antique dit de Berenice II, in: B. Bourgeois (Ed.), Thérapéia. Polychromie et restauration de la sculpture dans l'Antiquité (Techné, 40), Paris, 2014, pp. 81-84.

[14] P. Liverani, Per una 'Storia del colore.' La scultura policroma romana, in: P. Liverani, U. Santamaria (Eds.), Diversamente bianco. La policromia della scultura romana, Roma, 2014, pp. 9-23.

[15] M. Scharff, R. Hast, N. Kalsbeek, J.S. Østergaard, Investigating the polychromy of a Classical Attic Greek marble female head NCG IN 283013, in: Tracking colour. The 
Polychromy and Greek and Roman Sculpture in the Ny Carlsberg Glyptotek. Report 1,

[16] M.L. Sargent, L.R. Spaabek, M. Scharff, J.S. Østergaard, Documentation and investigation of traces of colour on the Archaic Sphinx NCG IN 1203 74, in: Tracking colour. The Polychromy and Greek and Roman Sculpture in the Ny Carlsberg Glyptotek. Report 1, Copenhagen, 2009, 74-88.

[17] I. Bonaduce, J. Boon, An integrated mass spectrometric and molecular imaging analytical approach to identify and localise constituents in paintings applied to gilded multilayer structures from 14th to 16th works of art, in: M. P Colombini \& L Tassi (Eds.), New trends in analytical, environmental and cultural heritage chemistry. Transworld Research Network, 345-388.

[18] F. Baratte, Fiche 73 - Tête-portrait masculine colossale, in: F. Baratte, N. de Chaisemartin, F. Béjaoui (Eds.), Corpus raisonné des sculptures du Musée du Bardo, Ausonius, Bordeaux (forthcoming).

[19] K. Fittschen, P. Zanker, Katalog der römischen Porträts in den Capitolinischen Museen und den anderen kommunalen Sammlungen der Stadt Rom. 1. Kaiser-und Prinzenbildnisse (Beiträge zur Erschliessung hellenistischer und kaiserzeitlicher Skulptur und Architektur iii.), Von Zabern, Mainz, 1985.

[20] J. Sanyova, S. Cersoy, P. Richardin, O. Laprévote, P. Walter, A. Brunelle, Unexpected materials in a Rembrandt painting characterized by high spatial resolution cluster-TOF-SIMS imaging, Analytical Chemistry 83 (2011), 753-760.

[21] P. Richardin, V. Mazel, P., Walter, O. Laprévote, A. Brunelle, Identification of different copper green pigments in Renaissance paintings by cluster-TOF-SIMS imaging analysis, Journal Of the American Society for Mass Spectrometry 22 (2011), 1729-1736.

[22] Q.P. Vanbellingen, N. Elie, M.J. Eller, S. Della-Negra, D. Touboul, A. Brunelle, Timeof-flight secondary ion mass spectrometry imaging of biological samples with delayed extraction for high mass and high spatial resolutions, Rapid Communications in Mass Spectrometry 29 (2015), 1187-1195.

[23] N. Noun, E. Van Elslande, D. Touboul, H. Glanville, S. Bucklow, P. Walter, A. Brunelle, High mass and spatial resolution mass spectrometry imaging of Nicolas Poussin painting cross-section by cluster-TOF-SIMS, Journal of Mass Spectrometry 51 (2016), 1196-1210.

[24] M. Regert, S. Colinart, L. Degrand, O. Decavallais, Chemical alteration and use of beeswax through time: accelerated ageing tests and analysis of archaeological samples from various environmental contexts, Archaeometry 43 (4) (2001), 549-569.

[25] A. Freccero, Encausto and ganosis. Beeswax as Paint and Coating during the Roman Era and its Applications in Modern Art, Craft and Conservation, Göteborg Studies in Conservation 9 (2002).

[26] J.K., Delaney, K.A., Dooley, R.Radpour, I. Kakoulli, Macroscale multimodal imaging reveals ancient painting production technology and the vogue in Greco-Roman Egypt (2017) Scientific Reports, 7 (1), art. no. 15509.

[27] E. Leka, L'emploi des huiles, des onguents et des parfums dans l'entretien des statues en Grèce ancienne, in Dominique Frère, Laurent Hugot (eds.), Les huiles parfumées en Méditerranée occidentale et en Gaule (VIIIe siècle av. - VIIIe siècle apr. J.-C.), Centre Jean 
Bérard n 38, Archéologie de l'artisanat antique, 6, Presses Universitaires de Rennes, 2012, p. 1389 277-290.

2

[28] B. Bourgeois, « Les vies d'une reine. A propos des remaniements antiques de polychromie sur le portrait de Bérénice II à Mariemont » in R. van den Hoff, F. Queyrel, E. Perrin-Saminadayar, Eikones. Portraits en contexte. Recherches nouvelles sur les portraits grecs $d u$ Ve au Ier s. av. J.-C., Venosa : Osanna Edizioni, 2016, p. 151-168. 

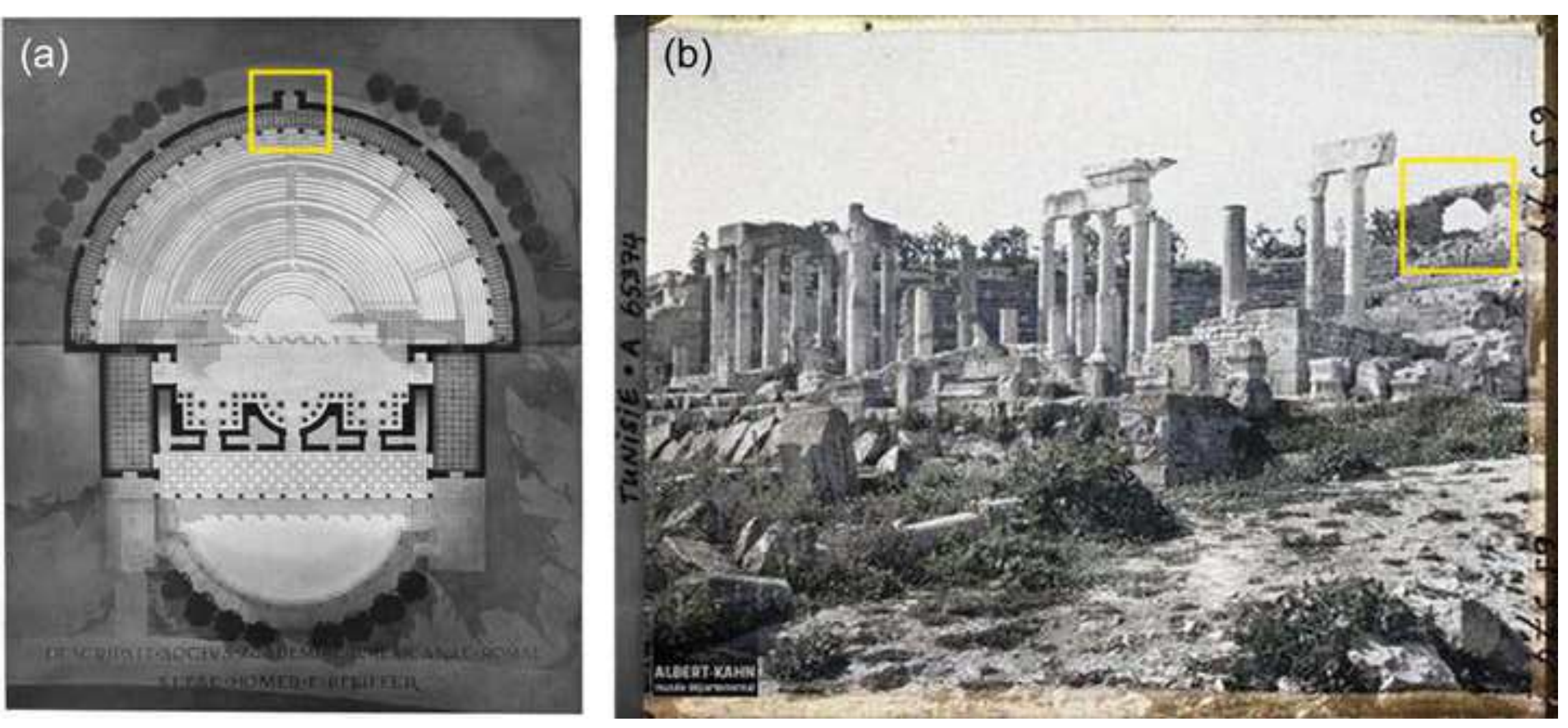
(a)

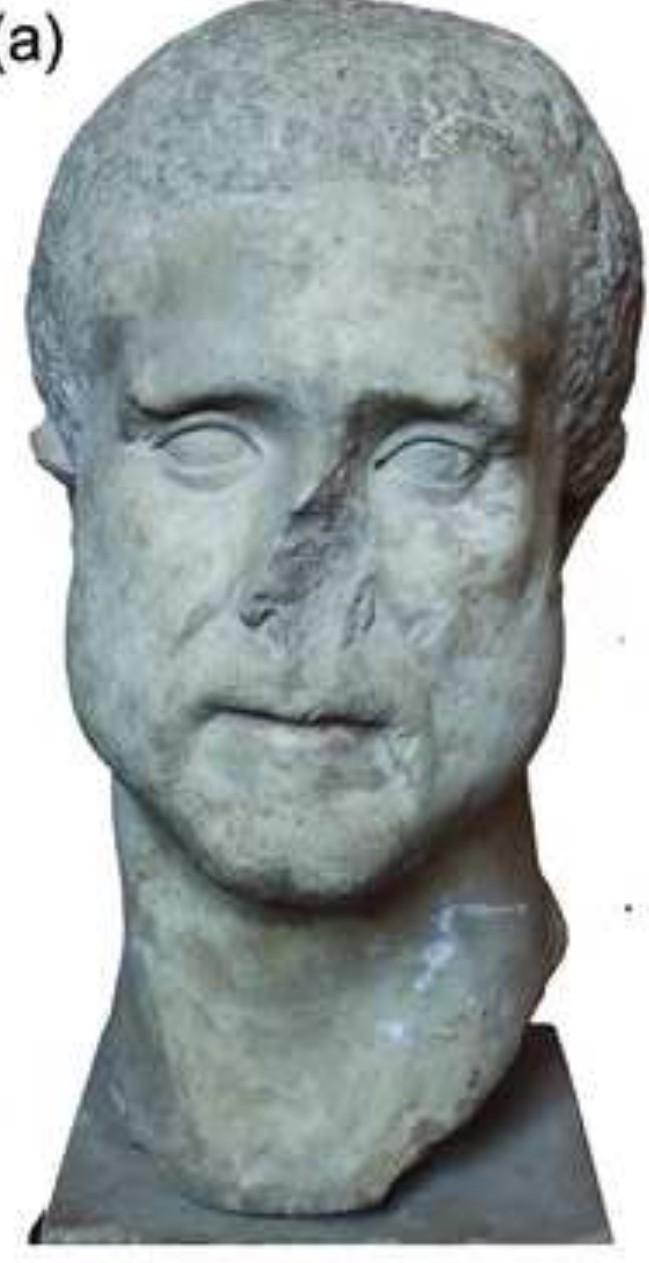

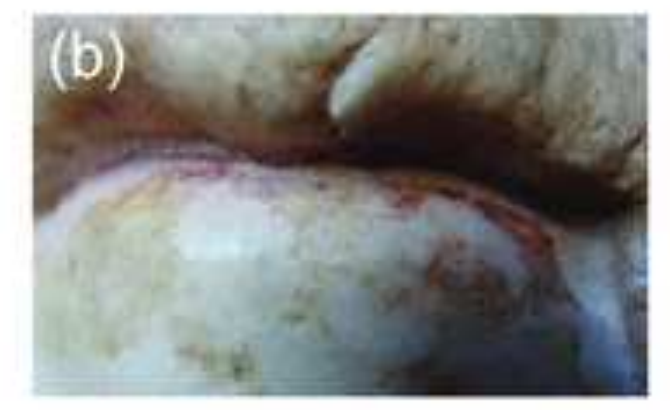
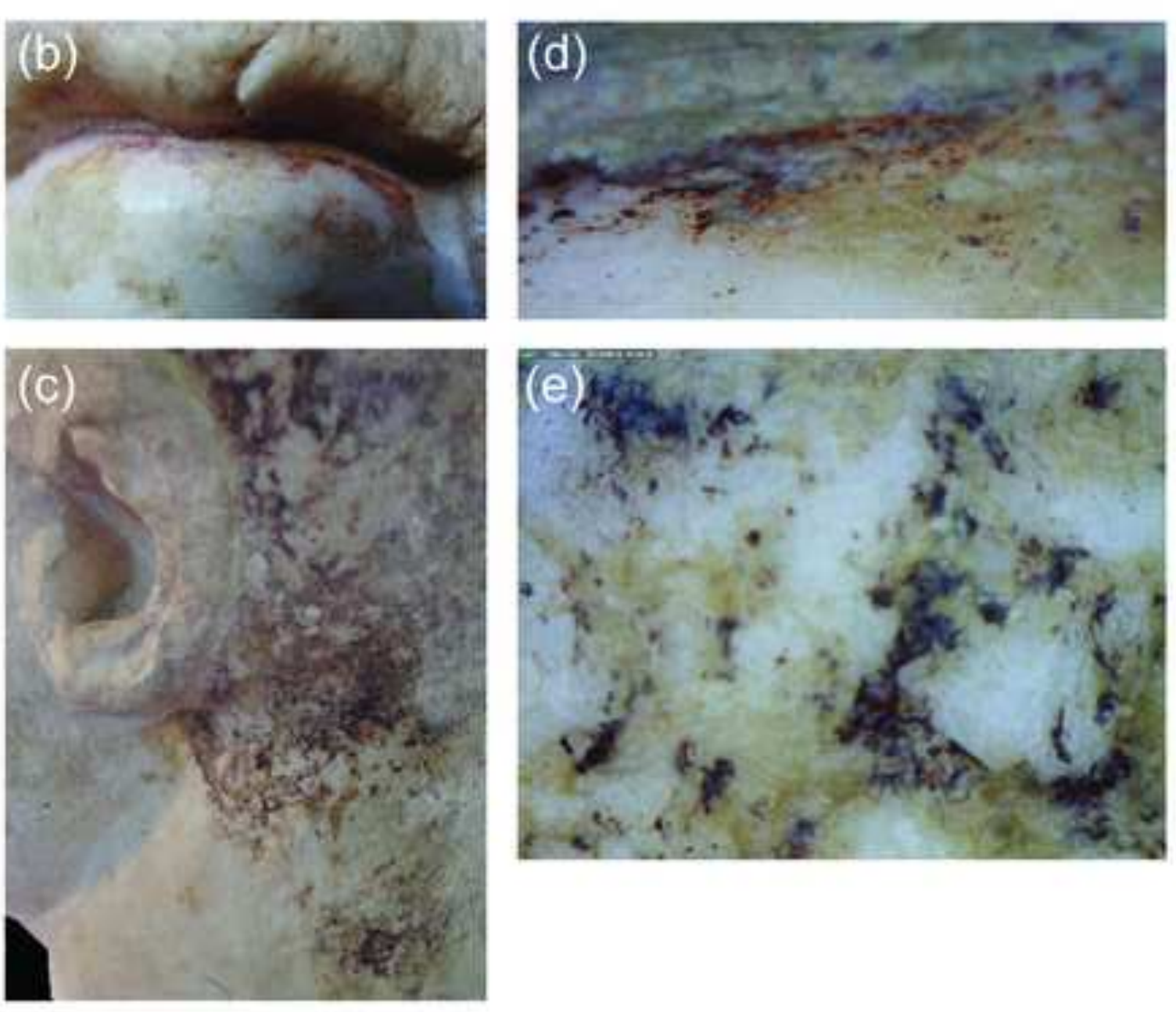

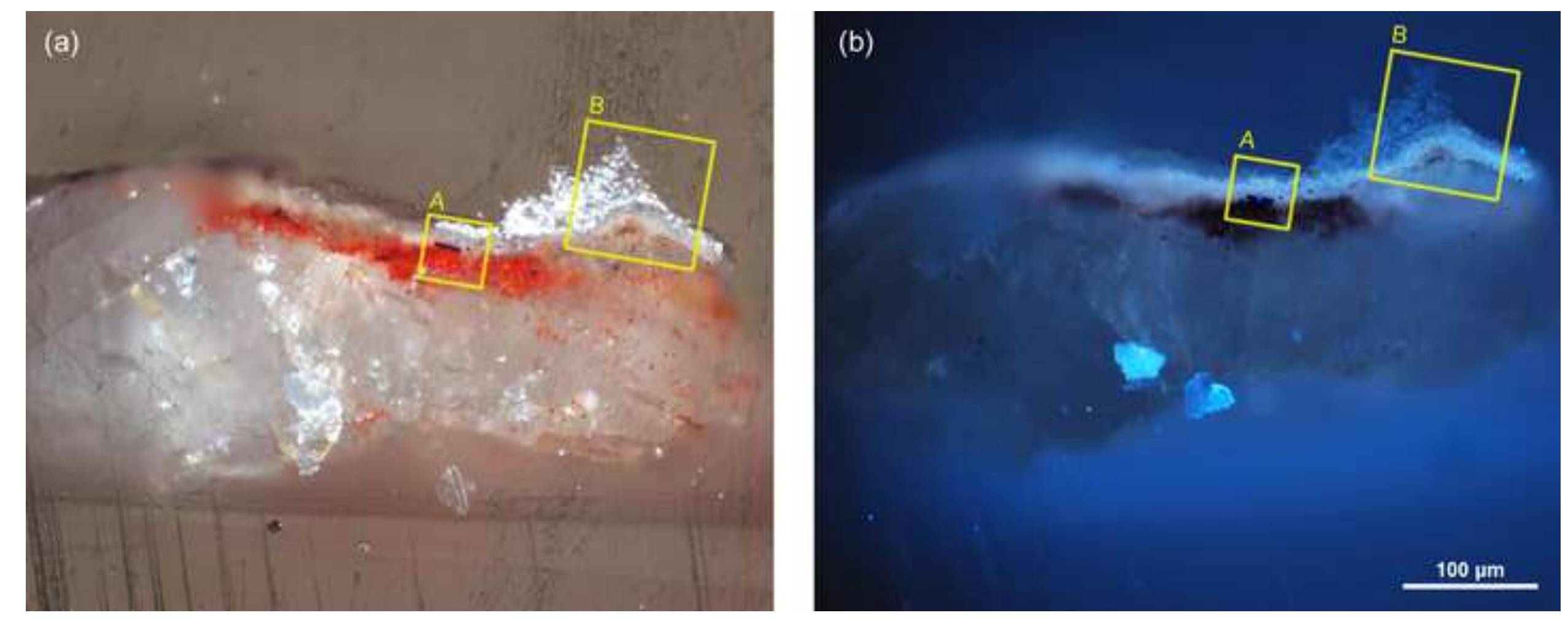


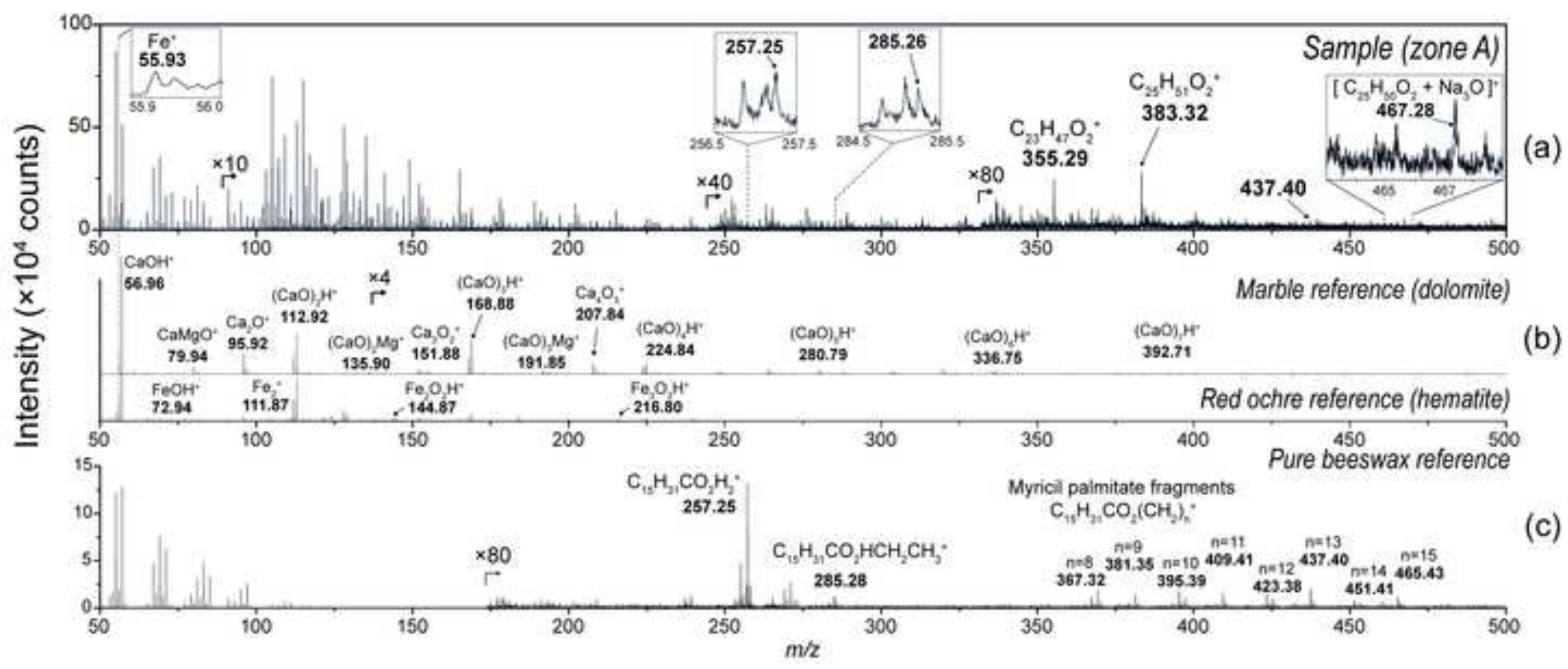




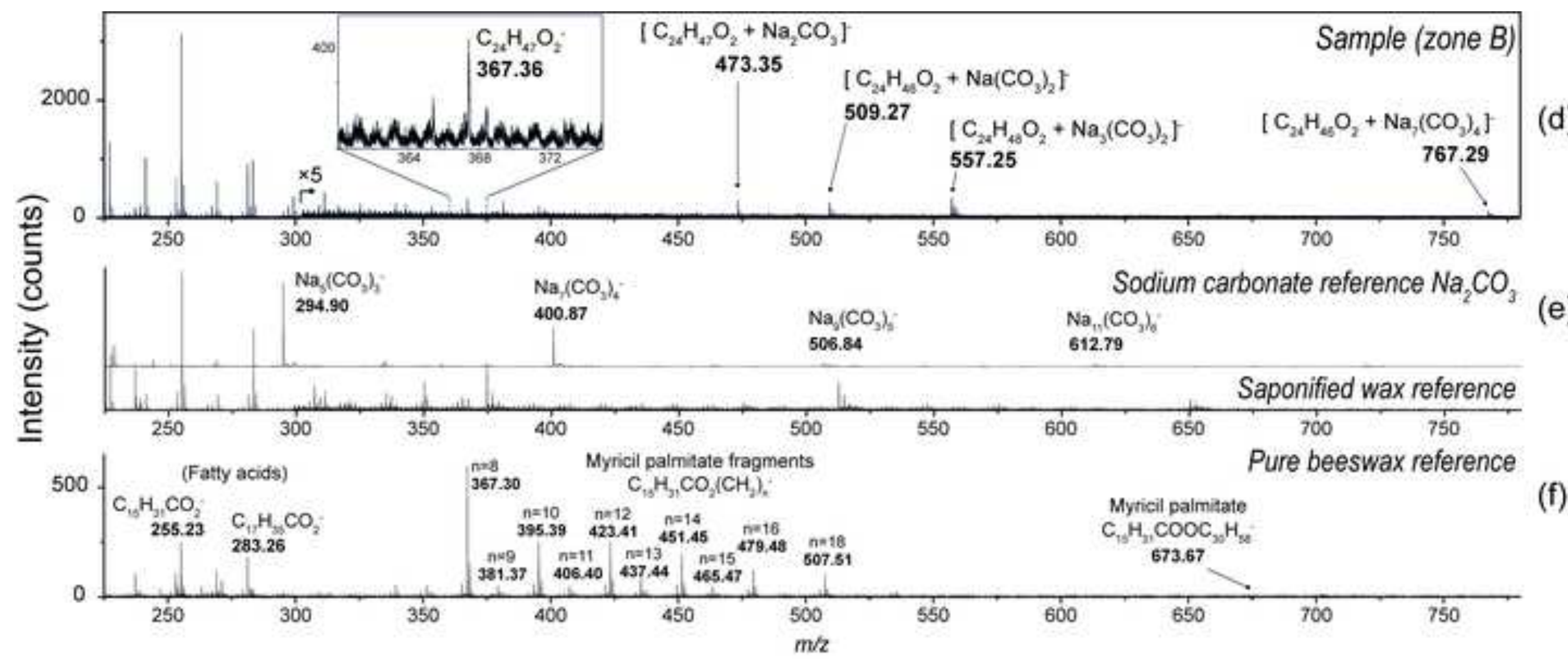




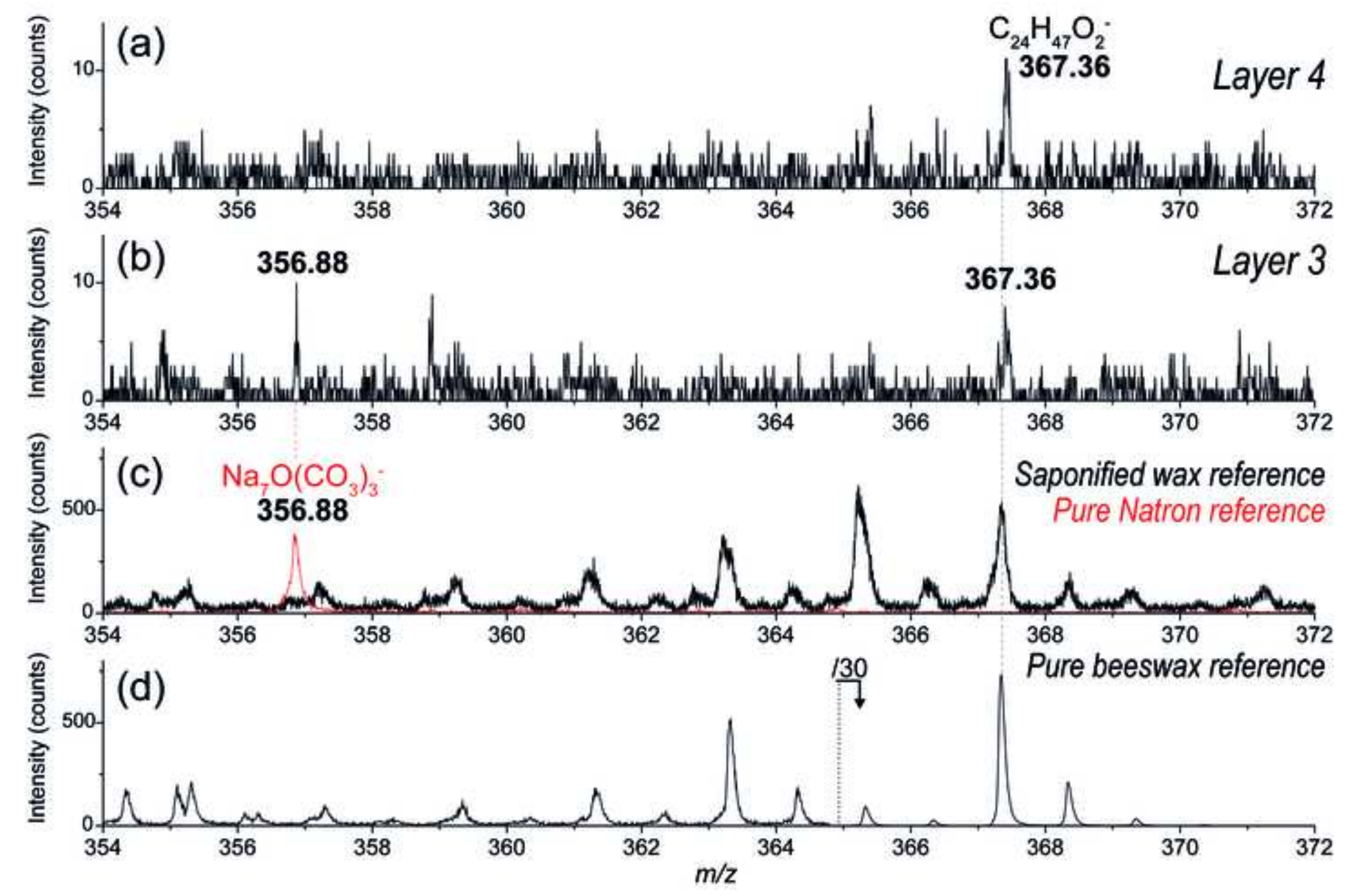




\section{(e)}

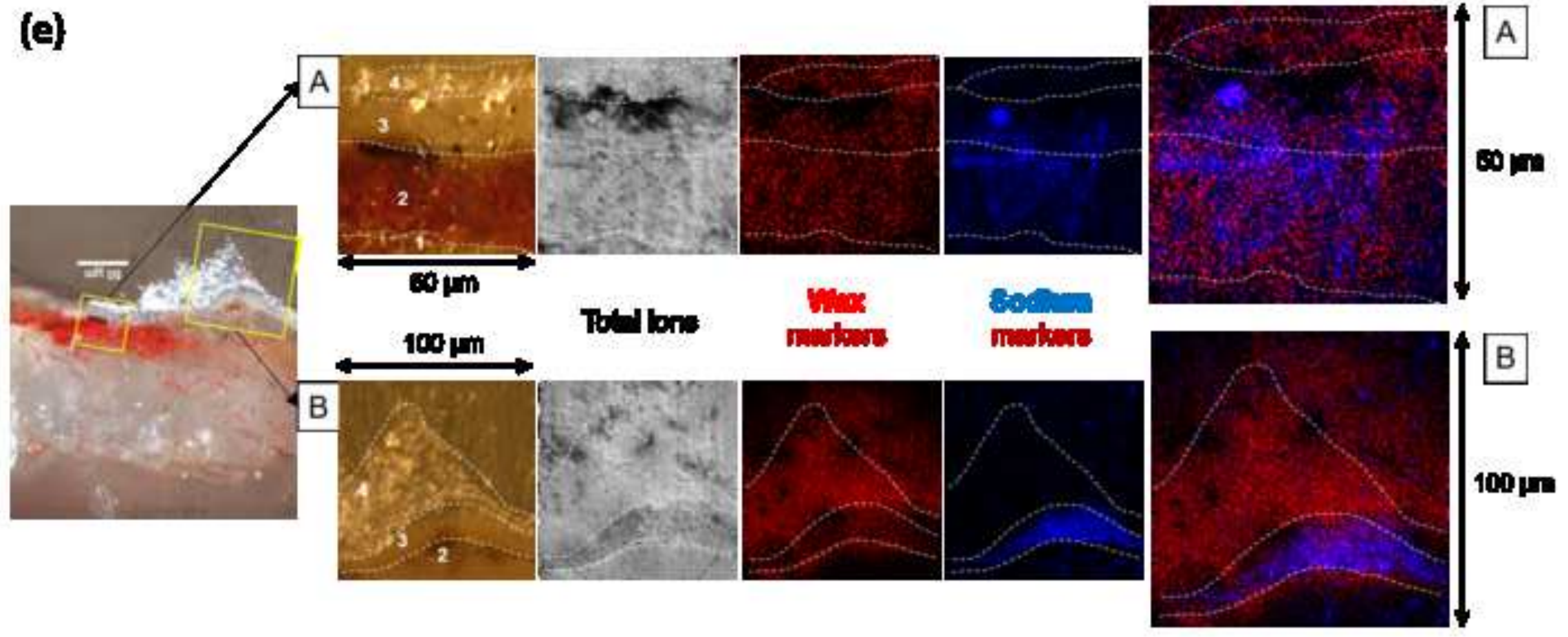


Table 1 : Characteristic ions from reference mass spectra and detected in the sample

\begin{tabular}{|c|c|c|c|c|c|}
\hline \multirow{2}{*}{\multicolumn{2}{|c|}{$\begin{array}{c}\text { Measured } m / z \\
\Delta: \text { standard } \\
\text { deviation }(\mathrm{ppm})\end{array}$}} & \multirow{3}{*}{\multicolumn{2}{|c|}{$\begin{array}{l}\text { Characteristic ions for positive polarity } \\
\text { (tentative assignments) }\end{array}$}} & \multicolumn{2}{|c|}{ Detected in... } \\
\hline & & & & Reference & Sample \\
\hline$m / z$ & $\Delta(\mathrm{ppm})$ & & & \multirow{5}{*}{$\begin{array}{c}\text { Marble } \\
\text { Kremer } \\
\text { Pigmente } \\
\text { n`58740 }\end{array}$} & \multirow{5}{*}{ Layer 1} \\
\hline 39.96 & 15 & \multicolumn{2}{|c|}{$\mathrm{Ca}^{+}$} & & \\
\hline 56.96 & -51 & \multicolumn{2}{|c|}{$\begin{array}{c}\mathrm{H}(\mathrm{CaO})^{+} \text {and associated } \mathrm{H}(\mathrm{CaO})_{\mathrm{n}}{ }^{+}(\mathrm{n}=2-7) \\
m / z 112.92,168.88,224.84,280.79,336.75,392.71\end{array}$} & & \\
\hline 79.94 & -15 & \multicolumn{2}{|c|}{$\begin{array}{c}\mathrm{Mg}(\mathrm{CaO})^{+} \text {and associated } \mathrm{Mg}(\mathrm{CaO})_{\mathrm{n}}{ }^{+}(\mathrm{n}=2-7) \\
m / z \text { 135.90, 191.85, 247.83, 303.76, 359.73, 415.68 }\end{array}$} & & \\
\hline 95.92 & 40 & \multicolumn{2}{|c|}{$\begin{array}{c}\mathrm{Ca}(\mathrm{CaO})^{+} \text {and associated } \mathrm{Ca}(\mathrm{CaO})_{\mathrm{n}}{ }^{+}(\mathrm{n}=2-5) \\
m / z, 151.88,207.84,263.80,319.74\end{array}$} & & \\
\hline 55.93 & -50 & \multicolumn{2}{|c|}{$\mathrm{Fe}^{+}$} & \multirow{3}{*}{$\begin{array}{l}\text { Hematite } \\
\text { Kremer } \\
\text { Pigmente } \\
n^{\circ} 40510\end{array}$} & \multirow{3}{*}{$\begin{array}{c}\text { Layer } 2 \\
\text { (particles below } \\
5 \mu \mathrm{m})\end{array}$} \\
\hline 111.87 & 30 & \multicolumn{2}{|c|}{$\mathrm{Fe}_{2}^{+}$} & & \\
\hline 72.94 & -14 & \multicolumn{2}{|c|}{$\begin{array}{c}\mathrm{FeOH}^{+} \text {and associated } \mathrm{H}(\mathrm{FeO})_{\mathrm{n}}{ }^{+}(\mathrm{n}=2-3) \\
m / z \text { 144.87, 216.80 }\end{array}$} & & \\
\hline 257.26 & 8 & \multicolumn{2}{|c|}{$\mathrm{C}_{15} \mathrm{H}_{31} \mathrm{CO}_{2} \mathrm{H}_{2}^{+}$} & \multirow{14}{*}{$\begin{array}{l}\text { Beeswax } \\
\text { (pure) }\end{array}$} & \multirow{14}{*}{$\begin{array}{l}\text { Layer } 2 \\
\text { Layer } 3 \\
\text { Layer } 4\end{array}$} \\
\hline 285.26 & -30 & \multicolumn{2}{|c|}{$\mathrm{C}_{15} \mathrm{H}_{31} \mathrm{CO}_{2} \mathrm{HC}_{2} \mathrm{H}_{5}^{+}$} & & \\
\hline 355.29 & -93 & \multicolumn{2}{|c|}{$\mathrm{C}_{15} \mathrm{H}_{31} \mathrm{CO}_{2} \mathrm{H}\left(\mathrm{CH}_{2}\right)_{6} \mathrm{CH}_{3}{ }^{+}$} & & \\
\hline 369.34 & -79 & \multicolumn{2}{|c|}{$\mathrm{C}_{15} \mathrm{H}_{31} \mathrm{CO}_{2} \mathrm{H}\left(\mathrm{CH}_{2}\right)_{7} \mathrm{CH}_{3}{ }^{+}$} & & \\
\hline 383.32 & -99 & \multicolumn{2}{|c|}{$\mathrm{C}_{15} \mathrm{H}_{31} \mathrm{CO}_{2} \mathrm{H}\left(\mathrm{CH}_{2}\right)_{8} \mathrm{CH}_{3}{ }^{+}$} & & \\
\hline 353.35 & & \multirow{9}{*}{$\begin{array}{c}\mathrm{C}_{15} \mathrm{H}_{31} \mathrm{CO}_{2}\left(\mathrm{CH}_{2}\right)_{\mathrm{n}}^{+} \\
\text {or } \\
\mathrm{O}\left(\mathrm{CH}_{2}\right)_{\mathrm{m}} \mathrm{CH}_{3}^{+}\end{array}$} & $\mathrm{n}=7$ or $\mathrm{m}=23$ & & \\
\hline 367.32 & & & $n=8$ or $m=24$ & & \\
\hline 381.35 & & & $\mathrm{n}=9$ or $\mathrm{m}=25$ & & \\
\hline 395.39 & & & $\mathrm{n}=10$ or $\mathrm{m}=26$ & & \\
\hline 409.41 & & & $\mathrm{n}=11$ or $\mathrm{m}=27$ & & \\
\hline 423.38 & & & $\mathrm{n}=12$ or $\mathrm{m}=28$ & & \\
\hline 437.40 & & & $\mathrm{n}=13$ or $\mathrm{m}=29\left(\mathrm{C}_{30} \mathrm{H}_{61} \mathrm{O}^{+}\right)$ & & \\
\hline 451.41 & & & $\mathrm{n}=14$ & & \\
\hline 465.43 & & & $\mathrm{n}=15$ & & \\
\hline \multirow{2}{*}{\multicolumn{2}{|c|}{$\begin{array}{c}\text { Measured } m / z \\
\Delta: \text { standard } \\
\text { deviation }(\mathrm{ppm})\end{array}$}} & \multirow{3}{*}{\multicolumn{2}{|c|}{$\begin{array}{l}\text { Characteristic ions for negative polarity } \\
\text { (tentative assignments) }\end{array}$}} & Det & ted in... \\
\hline & & & & Reference & Sample \\
\hline$m / z$ & $\Delta(\mathrm{ppm})$ & & & & \\
\hline 297.26 & & & $\mathrm{n}=3$ or $\mathrm{m}=19$ & & \\
\hline 311.28 & & & $\mathrm{n}=4$ or $\mathrm{m}=20$ & & \\
\hline 325.30 & & & $\mathrm{n}=5$ or $\mathrm{m}=21$ & & \\
\hline 339.32 & & & $\mathrm{n}=6$ or $\mathrm{m}=22$ & & \\
\hline 353.34 & & & $\mathrm{n}=7$ or $\mathrm{m}=23$ & & \\
\hline 367.36 & & & $\mathrm{n}=8$ or $\mathrm{m}=24$ & & \\
\hline 381.37 & & & $n=9$ or $m=25$ & & \\
\hline 395.39 & & $\mathrm{C}_{15} \mathrm{H}_{31} \mathrm{CO}_{2}\left(\mathrm{CH}_{2}\right)_{\mathrm{n}}{ }^{-1}$ & $\mathrm{n}=10$ or $\mathrm{m}=26$ & Beeswax & Layer 2 \\
\hline 409.46 & & $\begin{array}{c}\text { or } \\
\mathrm{O}\left(\mathrm{CH}_{2}\right)_{\mathrm{m}} \mathrm{CH}_{3}^{-}\end{array}$ & $\mathrm{n}=11$ or $\mathrm{m}=27$ & (pure) & $\begin{array}{l}\text { Layer } 3 \\
\text { Laver } 4\end{array}$ \\
\hline 423.41 & & & $\mathrm{n}=12$ or $\mathrm{m}=28$ & & \\
\hline 437.44 & & & $\mathrm{n}=13$ or $\mathrm{m}=29\left(\mathrm{C}_{30} \mathrm{H}_{61} \mathrm{O}^{+}\right)$ & & \\
\hline 451.45 & 55 & & $\mathrm{n}=14$ & & \\
\hline 465.47 & 7 & & $\mathrm{n}=15$ & & \\
\hline 479.48 & 83 & & $\mathrm{n}=16$ & & \\
\hline 493.48 & -88 & & $\mathrm{n}=17$ & & \\
\hline 507.51 & 2 & & $\mathrm{n}=18$ & & \\
\hline 673.67 & 78 & $\mathrm{C}_{15} \mathrm{H}$ & $\mathrm{OC}_{30} \mathrm{H}_{58}{ }^{-}$ & & \\
\hline
\end{tabular}




\begin{tabular}{|c|c|c|c|c|}
\hline 82.98 & 37 & $\mathrm{NaCO}_{3}^{-}$ & \multirow{9}{*}{$\begin{array}{c}\text { Beeswax } \\
\text { (saponified) }^{*}\end{array}$} & \multirow{9}{*}{$\begin{array}{l}\text { Layer } 2 \\
\text { Layer } 3\end{array}$} \\
\hline 137.96 & 30 & $\mathrm{Na}_{2} \mathrm{CO}_{5}^{-}$ & & \\
\hline 154.97 & 63 & $\mathrm{Na}_{2} \mathrm{CO}_{6} \mathrm{H}^{-}$ & & \\
\hline 162.96 & 35 & $\mathrm{NaO}_{5} \mathrm{CO}_{3}^{-}$ & & \\
\hline 178.96 & 37 & $\mathrm{Na}_{2}\left(\mathrm{CO}_{2}\right)_{3} \mathrm{H}^{-}$ & & \\
\hline 188.95 & 30 & $\mathrm{Na}_{3}\left(\mathrm{CO}_{3}\right)_{2}^{-}$ & & \\
\hline 294.90 & -11 & $\mathrm{Na}_{5}\left(\mathrm{CO}_{3}\right)_{3}{ }^{-}$ & & \\
\hline 334.91 & 25 & $\mathrm{Na}_{6}\left(\mathrm{CO}_{3}\right)_{3} \mathrm{OH}$ & & \\
\hline 356.88 & 25 & $\mathrm{Na}_{7}\left(\mathrm{CO}_{3}\right)_{3} \mathrm{O}^{-}$ & & \\
\hline 66.98 & 7 & $\begin{array}{c}\mathrm{NaCO}_{2}^{-} \text {and associated } \mathrm{Na}_{\mathrm{n}} \mathrm{CO}_{\mathrm{m}}{ }^{-}(\mathrm{n}=1-2 ; \mathrm{m}=2-5) \\
m / z 82.98,89.98,98.97,105.97,121.96,137.96\end{array}$ & \multirow{7}{*}{ Natron (pure) } & \multirow{7}{*}{$\begin{array}{l}\text { Layer } 2 \\
\text { Layer } 3\end{array}$} \\
\hline 156.95 & -18 & $\mathrm{Na}_{3}\left(\mathrm{CO}_{2}\right)_{2}^{-}$ & & \\
\hline 268.91 & 43 & $\mathrm{Na}_{7} \mathrm{CO}_{6}^{-}$ & & \\
\hline 308.91 & 4 & $\mathrm{Na}_{3}\left(\mathrm{CO}_{3}\right)_{4}^{-}$ & & \\
\hline 334.90 & -25 & $\mathrm{Na}_{6}\left(\mathrm{CO}_{3}\right)_{3} \mathrm{OH}$ & & \\
\hline 356.89 & -32 & $\mathrm{Na}_{7}\left(\mathrm{CO}_{3}\right)_{3} \mathrm{O}^{-}$ & & \\
\hline 400.87 & 5 & $\mathrm{Na}_{7}\left(\mathrm{CO}_{3}\right)_{4}^{-}$ & & \\
\hline
\end{tabular}

